\title{
Liquid biopsy provides new insights into gastric cancer
}

\author{
Camila Tavares Uchôa Guimarães ${ }^{1, *}$, Nina Nayara Ferreira Martins ${ }^{2, *}$, Kelly Cristina \\ da Silva Oliveira ${ }^{2}$, Caroline Martins Almeida ${ }^{1}$, Thayanne Macedo Pinheiro ${ }^{2}$, \\ Carolina Oliveira Gigek ${ }^{3,4}$, Sandro Roberto de Araújo Cavallero², Paulo Pimentel \\ Assumpção², Marília Arruda Cardoso Smith ${ }^{3}$, Rommel Rodríguez Burbano ${ }^{2,5}$ and \\ Danielle Queiroz Calcagno ${ }^{1,2}$ \\ ${ }^{1}$ Residência Multiprofissional em Oncologia, Hospital Universitário João de Barros Barreto, Universidade Federal do Pará, \\ Belém, PA, Brazil \\ ${ }^{2}$ Núcleo de Pesquisas em Oncologia, Universidade Federal do Pará, Belém, PA, Brazil \\ ${ }^{3}$ Disciplina de Genética, Universidade Federal de São Paulo, São Paulo, SP, Brazil \\ ${ }^{4}$ Disciplina de Gastroenterologia Cirurgica, Universidade Federal de São Paulo, São Paulo, SP, Brazil \\ ${ }^{5}$ Laboratório de Biologia Molecular, Hospital Ophir Loyola, Belém, PA, Brazil \\ *These authors contributed equally to this work
}

Correspondence to: Danielle Queiroz Calcagno, email: danicalcagno@gmail.com

Keywords: circulating tumor cells; circulating tumor DNA; circulating microRNAs; circulating long non-coding RNAs; precision medicine

Received: July 26, 2017 Accepted: December 01, 2017 Epub: February 21, 2018 Published: March 13, 2018

Copyright: Guimarães et al. This is an open-access article distributed under the terms of the Creative Commons Attribution License 3.0 (CC BY 3.0), which permits unrestricted use, distribution, and reproduction in any medium, provided the original author and source are credited.

\section{ABSTRACT}

Liquid biopsies have great promise for precision medicine as they provide information about primary and metastatic tumors via a minimally invasive method. In gastric cancer patients, a large number of blood-based biomarkers have been reported for their potential role in clinical practice for screening, early diagnosis, prognostic evaluation, recurrence monitoring and therapeutic efficiency follow-up. This current review focuses on blood liquid biopsies' role and their clinical implications in gastric cancer patients, with an emphasis on circulating tumor cells (CTCs), circulating tumor DNA (ctDNA) and circulating non-coding RNAs (ncRNAs). We also provide a brief discussion of the potential and limitations of liquid biopsies use and their future use in the routine clinical care of gastric cancer.

\section{INTRODUCTION}

Among the various types of cancer that affect humans, gastric cancer (GC) is the fifth most frequent tumor type and the third leading cause of cancer death worldwide [1]. The high mortality rate presents a major clinical challenge because most GC cases are diagnosed at an advanced stage with poor prognosis, limited treatment options, and frequent metastasis and recurrence [2].

The sensitivity and specificity of current blood biomarkers for $\mathrm{GC}$ are insufficient to define the diagnosis and prognosis. In general, a GC diagnosis relies on an upper digestive endoscopy, an invasive procedure with a relatively high cost and unusual but serious adverse events $[3,4]$. In addition, a single tumor-biopsy may not represent the intratumoral heterogeneity and can contribute to treatment failure and drug resistance [5]. Thus, new promising analyses of liquid biopsies should be further explored and validated for use in a clinical setting in GC patients.

Liquid biopsies have emerged as a new strategy for use in the clinical treatment of different cancer types to provide early disease detection, determine the tumor genomic profile, monitor treatment responses, assess the emergence of therapy resistance, quantify minimal residual disease, and perform real-time cancer management [6].

Originally, the term liquid biopsy had been assigned only to the investigation of circulating tumor cells (CTCs) in the blood of patients with cancer, but has now been extended primarily to include the analysis of circulating tumor DNA (ctDNA) and circulating non-coding RNAs (ncRNAs) [7].

In the current review, we highlight the recent advances in liquid biopsies and examine how different forms of liquid biopsies can be exploited to improve GC patient care. We argue that they should ultimately be 
integrated into clinical practice for GC management, with a focus on CTCs, ctDNA and circulating ncRNAs.

\section{CIRCULATING TUMOR CELLS (CTCs)}

Circulating tumor cells (CTCs) have been identified as predictive and prognostic biomarkers that are useful for clinical approaches. They can determine risk for metastasis and can provide real-time monitoring of the therapeutic response in cancer patients [7]. Table 1 summarizes known CTCs as potential prognostic biomarkers and their utility for the evaluation of therapeutic efficacy in GC [8-29].

In general, CTCs are rare in peripheral blood circulation and are found at a concentration of less than 5 CTCs per $7.5 \mathrm{ml}$ of blood [30]. Furthermore, these CTCs originate from either primary or metastatic tumors [31], present a heterogeneous population and express the antigenic or genetic characteristics of a specific tumor type [32].

Early studies of CTCs characterized them as nucleated cells that express markers of epithelial cells EpCAM and cytokeratin 8, 18, and 19 (CK8, CK18, CK19), but are negative for CD45 (CD45-) [33]. Recent studies have described subpopulations of CTCs undergoing the epithelial mesenchymal transition (EMT) that may show decreased expression of EpCAM and cytokeratin with potential overexpression of mesenchymal markers, including Vimentin and Twist [34, 16]. In addition, it is also possible for these CTCs to undergo the reverse process, termed the mesenchymal epithelial transition (MET), resulting in subpopulations of CTCs that present mesenchymal and epithelial markers [35].

CTCs with mesenchymal phenotypes could have a greater propensity for tumor escape due to larger plasticity, thus facilitating the invasion and migration process [36, 37]. Moreover, CTCs with mesenchymal markers seem to be more resistant to chemotherapeutic drugs [38].

Concerning GC, Li et al. [16] indicated five types of cells including exclusively epithelial $\left(\mathrm{E}^{+}\right)$CTCs, exclusively mesenchymal $\left(\mathrm{M}^{+}\right)$CTCs and intermediate CTCs $\left(\mathrm{E}^{+}>\mathrm{M}^{+} ; \mathrm{E}^{+}=\mathrm{M}^{+} ; \mathrm{M}^{+}>\mathrm{E}^{+}\right)$, using a filtrationbased method and EpCAM, CK8, CK18, CK19, Vimentin and Twist as markers. These authors observed that approximately $11 \%(4 / 35)$ of patients formed a subgroup exclusively with $\mathrm{M}^{+}$CTCs and $29 \%$ (10/35) of patients had subgroups $\mathrm{M}^{+}$and $\mathrm{M}^{+}>\mathrm{E}^{+}$, just one patient had the CTCs subgroups $\mathrm{E}^{+}>\mathrm{M}^{+}$and no patient with the CTCs subgroup that was exclusively E+. Taken together, these findings demonstrated the heterogeneity of CTCs and their predominantly mesenchymal phenotype, suggesting a limitation of the methodologies that only just epithelial markers to enumerate CTCs in GC.

Although the CellSearch ${ }^{\mathrm{TM}}$ platform (Veridex LLC, Huntingdon Valley, PA, USA) uses antibodies against the adhesion molecule (EpCAM)-coated with magnetic beads, cytokeratin (CK8, CK18 and CK19) antibodies and negative staining for the CD45 (CD45-) antibody to isolate and exclusively quantify the E+ CTCs, it remains the main method used in GC studies and is the only technique approved for the enumeration and isolation of CTCs by the Food and Drug Administration (FDA) for clinical use in the prognosis of breast, colorectal and prostate cancer [39].

Additional characterization of CTCs can identify specific morphological, phenotypic and molecular features for each cancer type over time, disease stage and therapeutic definition [40]. For instance, Iwatsuki et al. [14] evaluated CTCs and their HER2 status in gastrointestinal cancer patients; overexpression of HER2 is a selective biomarker for treatment with the monoclonal antibody Trastuzumab in metastatic GC. In GC patients, these authors detected at least one CTC (CTC $\geq 1)$ in $73.5 \%(25 / 34)$ of samples that were $28 \%(7 / 25)$ HER2 positive. However, a discordant HER2 status was found between CTC-positive cases and corresponding primary tumors (HER2-positive CTCs/ HER2-negative primary tumor tissue), suggesting that primary HER2-negative tumors acquired HER2 gene amplification in their CTCs during cancer progression. Therefore, the HER2 status of CTCs might be required as a liquid biopsy to provide personalized treatment strategies in GC.

Several studies have observed the aneuploidy of chromosome 8 in CTCs from GC patients [41, 17, 25], a frequent genetic abnormality reported in $\mathrm{GC}$ tumors and cell lines [42-47]. Interestingly, $\mathrm{Li}$ et al. [41] established an integrated subtraction enrichment (SET) and immunostaining-fluorescence in situ hybridization (iFISH) platform to detect and characterize CTCs that correlated with different ploidies of chromosome 8 in advanced GC (AGC) patients. These authors suggested that SET iFISH is significantly more sensitive than the CellSearch ${ }^{\mathrm{TM}}$ method to enumerate CTCs.

Recently, two studies performed SET-iFISH to enumerate CTCs with chromosome 8 aneuploidy before and after treatment in advanced gastric cancer (AGC) patients. Ma et al. [17] observed a marked expressive reduction in CTCs number with chromosome 8 amplification in patients after neoadjuvant therapy with Docetaxel/Oxaliplatin/5-FU (DOF) plus Bevacizumab compared to patients treated with DOF alone, suggesting that the addition of bevacizumab, a VEGF inhibitor, could decrease CTC counts. In addition, Li et al. [23] quantified CTCs and analyzed their chromosome 8 multiploidy in patients before and after therapy with the first-line (paclitaxel or cisplatin) or targeted therapy (anti-HER2 and cisplatin) and correlated these findings with the patient's clinical prognosis. AGC patients who have an unfavorable CTC value ( $\geq 4$ CTCs) and an unfavorable CTC multiploidy value ( $\geq 2$ per $7.5 \mathrm{~mL}$ ) following therapy showed a significant association with poor progressionfree survival (PFS) and overall survival (OS). Moreover, patients with $\geq 10 \%$ increase in multiploid CTCs after the first 2 cycles of therapy had a greater risk of progression and mortality than patients with a decrease number of 


\section{Table 1: CTCs and their clinical implication in GC patients}

\begin{tabular}{|c|c|c|c|c|c|}
\hline Markers & Methodology & Samples & Country & Clinical Implications & References \\
\hline $\begin{array}{l}\text { CEA, CK19, hTERT } \\
\text { and MUC1 mRNA }\end{array}$ & qRT-PCR & $64 \mathrm{GC}$ & China & $\begin{array}{l}\text { The membrane array-based method is a potential tool } \\
\text { for detecting CTCs for early diagnosis and postoperative } \\
\text { surveillance. }\end{array}$ & {$[8]$} \\
\hline $\begin{array}{l}\text { EpCAM, CK8, CK18, } \\
\text { CK19 and CD45- }\end{array}$ & CellSearch & $41 \mathrm{GC}$ & Japan & $\begin{array}{l}\text { CTCs number associated with advanced stage, peritoneal } \\
\text { dissemination, metastasis and poor survival. }\end{array}$ & {$[9]$} \\
\hline $\begin{array}{l}\text { BIRC5, CEA, CK19 } \\
\text { and VEGF }\end{array}$ & qRT- PCR & $70 \mathrm{GC}$ & Italy & $\begin{array}{l}\text { BIRC5 has a significant prognostic value to the current TNM } \\
\text { staging system. }\end{array}$ & {$[10]$} \\
\hline $\begin{array}{l}\text { EpCAM, CK8, CK18, } \\
\text { CK19 and CD45- }\end{array}$ & CellSearch & $52 \mathrm{AGC}$ & Japan & $\begin{array}{l}\text { CTCs enumeration may be useful as a marker for determining } \\
\text { response to S1-based or paclitaxel regimens in AGC. }\end{array}$ & {$[11]$} \\
\hline piR-651 and piR-823 & qRT-PCR & $93 \mathrm{GC}$ & China & $\begin{array}{l}\text { Levels of piR- } 651 \text { and piR- } 823 \text { could be useful to diagnosis } \\
\text { GC with high sensitivity and specificity. }\end{array}$ & {$[12]$} \\
\hline $\begin{array}{l}\text { EpCAM, CK8, CK18, } \\
\text { CK19 and CD45- }\end{array}$ & CellSearch & $265 \mathrm{GC}$ & Japan & CTCs associated with significantly worse OS. & {$[13]$} \\
\hline $\begin{array}{l}\text { EpCAM, CK8, CK18, } \\
\text { CK19, CD45- and } \\
\text { HER2 }\end{array}$ & CellSearch & $34 \mathrm{GCM}$ & Japan & $\begin{array}{l}\text { HER2 status of CTCs might be helpful for stratification of } \\
\text { HER2-directed therapy. }\end{array}$ & {$[14]$} \\
\hline CD44+ and CD45- & FACS & $31 \mathrm{GC}$ & China & $\begin{array}{l}\text { CD44+/CD45-CTCs were associated with stronger malignant } \\
\text { behavior and relatively sensitive to fluorouracil, cisplatin and } \\
\text { paclitaxel, but relatively resistant to irradiation, oxaliplatin, } \\
\text { cetuximab and trastuzumab. }\end{array}$ & {$[15]$} \\
\hline $\begin{array}{l}\text { EpCAM, CK8, CK18, } \\
\text { CK19, Vimentin, Twist } \\
\text { and CD45- }\end{array}$ & $\begin{array}{l}\text { CanPatrol } \\
\text { (RNA-ISH) }\end{array}$ & $44 \mathrm{GC}$ & China & $\begin{array}{l}\text { Mesenchymal CTCs have a potential relevance to therapy } \\
\text { response and can be useful on a therapeutic resistance. }\end{array}$ & {$[16]$} \\
\hline Chromosomes 7 and 8 & FISH & $8 \mathrm{AGC}$ & China & $\begin{array}{l}\text { Reduction in CTCs count showed beneficial results to the } \\
\text { patients treated with docetaxel/oxaliplatin/5-FU (DOF) } \\
\text { regimen plus bevacizumab. }\end{array}$ & {$[17]$} \\
\hline $\begin{array}{l}\text { EpCAM, MUC1, } \\
K R T 19, M U C 1, \\
C E A C A M 5, E P C A M \\
\text { and BIRC5 }\end{array}$ & $\begin{array}{l}\text { Immunomagnetic } \\
\text { and RT-PCR }\end{array}$ & $62 \mathrm{AGC}$ & Germany & $\begin{array}{l}\text { A combination of immunomagnetic separation of CTC } \\
\text { followed by a real-time RT-PCR analysis of } K R T 19, M U C 1 \text {, } \\
E P C A M, C E A C A M 5 \text { and } B I R C 5 \text { can serve as a prognostic tool } \\
\text { for PFS and OS in patients with AGC. }\end{array}$ & {$[18]$} \\
\hline CD133 and ABCG2 & $\begin{array}{l}\text { Flow } \\
\text { cytometry and } \\
\text { Immunomagnetic }\end{array}$ & $36 \mathrm{GC}$ & China & $\begin{array}{l}\text { Presence of CD133 in bloodstream is potentially correlated } \\
\text { with potentially be used as a marker of CTCs. }\end{array}$ & [19] \\
\hline $\begin{array}{l}\text { EpCAM, CK8, CK18, } \\
\text { CK19, CD45-, CD19, } \\
\text { CD20, CD40, CD44, } \\
\text { CD133, CEA and HLA }\end{array}$ & $\begin{array}{l}\text { CellSearch and } \\
\text { Flow cytometry }\end{array}$ & $42 \mathrm{AGC}$ & Japan & $\begin{array}{l}\text { CD44 is an appropriate biomarker of tumorigenic cells on } \\
\text { peripheral blood. }\end{array}$ & {$[20]$} \\
\hline $\begin{array}{l}\text { EpCAM, CK8, CK18, } \\
\text { CK19 and CD45- }\end{array}$ & CellSearch & $136 \mathrm{AGC}$ & Japan & $\begin{array}{l}\text { Detection of CTCs was an independent predictor of a shorter } \\
\text { PFS and could be a useful biomarker in the selection of patients } \\
\text { who require intensive treatment in AGC. In addition, combined } \\
\text { status of CTC and CY would be useful in selecting patients for } \\
\text { radical gastrectomy. }\end{array}$ & {$[21]$} \\
\hline OBP-401 & FP-CTC Assay & $37 \mathrm{GC}$ & Japan & $\begin{array}{l}\text { The number of CTCs (S-GFP+ cells) was relatively high in } \\
\text { samples from GC patients who had received postoperative } \\
\text { chemotherapy. However, no significant association between } \\
\text { the change in the number of CTCs, treatment or prognosis in } \\
\text { gastric cancer patients who underwent curative surgery. }\end{array}$ & {$[22]$} \\
\hline $\begin{array}{l}\text { CK4, CK5, CK6, } \\
\text { CK8, CK10, CK13, } \\
\text { CK18, CD45- and } \\
\text { Chromosome } 8\end{array}$ & SE-iFISH & $31 \mathrm{AGC}$ & China & $\begin{array}{l}\text { Aneuploidy of chromosome } 8 \text { in CTCs is associated with a } \\
\text { poor prognosis. }\end{array}$ & {$[23]$} \\
\hline $\begin{array}{l}\text { EpCAM, CK7, CK18, } \\
\text { CK19,CK20, CD45-, } \\
\text { CD68, MUC1, HER2 } \\
\text { and EGFR }\end{array}$ & MetaCell & $22 \mathrm{GC}$ & Poland & $\begin{array}{l}\text { Higher sensitivity of CTC detection could be using a } \\
\text { cytomorphological and molecular analysis. }\end{array}$ & {$[24]$} \\
\hline
\end{tabular}




\begin{tabular}{|c|c|c|c|c|}
\hline $\begin{array}{l}\text { EpCAM, CK8, CK18, } \\
\text { CK19 and CD } 45-\end{array}$ & CellSearch & $136 \mathrm{GC}$ & China & $\begin{array}{l}\text { Post-treatment CTCs levels can help to evaluate therapeutic } \\
\text { response and predict their prognosis in patients with AGC. }\end{array}$ \\
\hline $\begin{array}{l}\text { EpCAM, CK8, CK18, } \\
\text { CK19, CD45- and } \\
\text { c-MET }\end{array}$ & $\begin{array}{l}\text { CellSearch and } \\
\text { Immunomagnetic }\end{array}$ & 7 GEA & USA & $\begin{array}{l}\text { c-MET CTCs might be useful as a predictive biomarker for } \\
\text { c-MET directed therapies. }\end{array}$ \\
\hline $\begin{array}{l}\text { EpCAM, CK and } \\
\text { CD45- }\end{array}$ & FAST-disc & $116 \mathrm{GC}$ & Korea & $\begin{array}{l}\text { Potential role of FAST-based CTC detection as an early } \\
\text { diagnostic biomarker of GC. }\end{array}$ \\
\hline $\begin{array}{l}\text { Vimentin, CK8, CK } 18 \text {, } \\
\text { CK19, CD45- and } \\
\text { CA125 }\end{array}$ & ISET & $86 \mathrm{GC}$ & China & $\begin{array}{l}\text { CTCs could be divided into epithelial CTCs, epithelial/ } \\
\text { mesenchymal CTCs, and mesenchymal CTCs, whereas } \\
\text { CTM could be divided into two subpopulations, including } \\
\text { mesenchymal CTM and partially mesenchymal (epithelial/ } \\
\text { mesenchymal) CTM. Moreover, CTM were a independent } \\
\text { predictor of worse PFS and OS in stage IV patients. }\end{array}$ \\
\hline $\begin{array}{l}\text { EpCAM, CK8, CK18, } \\
\text { CK19, CD45- and } \\
\text { HER2 }\end{array}$ & $\begin{array}{l}\text { CellSearch and } \\
\text { IF-FISH }\end{array}$ & $118 \mathrm{GC}$ & Japan & $\begin{array}{l}\text { IF-FISH method is applicable for select patients for } \\
\text { trastuzumab therapies. }\end{array}$ \\
\hline
\end{tabular}

AGC: advanced gastric cancer; CTM: circulating tumor microemboli; CY: peritoneal lavage cytology; EMT: epithelial-mesenchymal transition; FACS: fluorescence activated cell sorter; FAST: fluid-assisted separation technique; GC: gastric cancer; GCM: gastric cancer with metastasis; GEA: gastroesophageal adenocarcinoma; IF-FISH: immunofluorescence integrated with immunostaining-fluorescence in situ hybridization; ISET: isolation by size of epithelial tumor cells; PFS: progression-free survival; OS: overall survival; SE-iFISH: enrichment (SE) integrated with immunostaining-fluorescence in situ hybridization; RNA-ISH: RNA in situ hybridization.

multiploidy CTCs. These studies suggested that the use of SET-iFISH to enumerate CTCs with chromosome 8 aneuploidy is an efficient method to monitor the treatment response of GC patients.

In addition, many studies have reported that the presence of CTCs in circulating tumor microemboli (CTM) confer a survival advantage in the circulatory system compared to single CTCs, which indicate poor prognosis and influence disease progression [48, 49]. In GC, Zheng et al. [28] observed CTCs in 59\% (51/86) of GC patients in clinical stage I to IV, but CTMs were only found in $24 \%$ $(10 / 41)$ of GC patients in stage IV. They concluded that the group that was CTM-positive had worse PFS and OS than the CTM-negative group $(p<0.001)$. Thus, CTM could be useful to predict prognosis in GC.

\section{CIRCULATING TUMOR DNA (ctDNA)}

DNA fragments available in the blood stream, known as ctDNA, derived from primary tumor cells, CTCs and/or distant metastasis can reflect specific genetic cancer alterations, including mutations, amplifications, copy number variation $(\mathrm{CNV})$, rearrangement and methylation $[50,51]$.

Accumulating evidence has demonstrated that ctDNA detection is a minimally invasive method with potential clinical applications in cancer, including i) early detection of cancer; ii) monitoring of intratumoral heterogeneity and metastasis; iii) therapeutic target identification; iv) real-time evaluation of treatment response and tumor relapse; and v) real-time evaluation of drugs resistance [52].

So far, limited studies on the identification and monitoring of ctDNA levels in GC patients have been performed. Hamakawa et al. [53] reported that 30\% (3/10) of AGC patients had TP53 mutations in their primary tumors and preoperative ctDNA, suggesting that identification of the TP53 mutation (c.103delT; c. $747 \mathrm{G}>\mathrm{C}$; c. $166 \mathrm{G}>\mathrm{T}$ ) is a useful tool to monitor progression and residual disease during the clinical follow-up.

In 2016, Fang et al. [54] analyzed the mutational profile of eight genes (ARIDIA, TP53, PIK3CA, PTEN, $A K T 3, B R A F, A K T 2$ and $A K T 1$ ) and the altered levels of ctDNA in 277 patients with primary gastric tumors. The authors found that TP53, ARIDIA and PI3KCA were the most frequently mutated genes in AGC patients. Furthermore, they also found that patients with greater ctDNA levels were more likely to exhibit vascular invasion and a poor 5-year global survival rate than patients without detected ctDNA. Therefore, the highest ctDNA detectable levels were associated with peritoneal recurrence and a poor outcome in patients with AGC.

In addition, Shoda et al. [55] reported on potential of ctDNA for the detection of HER2 amplification determined by real-time quantitative PCR (qRT-PCR) in AGC patients before surgery and during postoperative treatment, highlighting spatial and/or temporal tumor heterogeneities. Unfortunately, quantitative information using qRT-PCR is obtained from the cycle threshold $(\mathrm{Ct})$ and these values can be affected by amplification imperfections that reduce efficiencies and limit the accuracy of this method for absolute quantification. On the other hand, the digital droplet PCR (ddPCR) method improves upon these limitations of nucleic acid quantification.

In 2017, Shoda et al. [56] showed the clinical utility of HER2 ratios in GC patients during treatment progression and demonstrated the HER2 status during 
real time evaluations using ddPCR method. Postoperative follow-ups revealed high plasma HER2 ratios at the time of recurrence in $53.84 \%(7 / 13)$ cases, even in cases that were diagnosed as being HER 2 negative at the time of surgery. Overall, detection of the HER 2 ratio by digital droplet PCR (ddPCR) could provide a window of opportunity for novel decision-making treatment strategies based on HER2 status at different periods in a clinical setting.

In a GC ctDNA meta-analysis, Gao et al. [57] demonstrated a significantly association between the ctDNA level based on gene methylation with the TNM stage, tumor depth, lymph node metastasis and distant metastasis in GC patients with high specificity $(0.95,95 \%$ CI $0.93-0.96)$ and relatively moderate sensitivity (0.62, 95\% CI 0.59-0.65).

Recently, periodic mutation profiling of ctDNA from stage IV GC patients by Next Generation Sequencing (NGS) revealed the complex and heterogeneous molecular mechanisms for crizotinib resistance after two months of treatment, including reoccurrence of $M E T$ amplification, multiple secondary MET mutations (D1228, Y1230, V1092, G1163 and L1195), a remarkable increase in the relative copy number of the FGFR2 gene as well as mutations in other downstream and related elements [58]. Crizotinib, a potent MET inhibitor, has demonstrated promising effects for the treatment of MET-amplified esophagogastric cancer $[59,60]$. Moreover, MET amplification has been reported to occur in approximately $5 \%$ of GC patients and is targeted by crizotinib, which is currently undergoing a clinical trial in advanced METpositive GC. However, tumors experienced progression shortly after crizotinib treatment [59]. Therefore, ctDNA profiling for treatment decision-making and prognosis in clinical practice have demonstrated great potential to elucidate mechanisms of resistance.

Overall, regular analysis by NGS is more expensive than ddPCR for ctDNA quantification method. Also, NGS practical use reveals an information reservoir unnecessarily for objective decision-making in clinical setting. Consequently, ddPCR could be well applied in clinical practice to identify relevant genetic aberrations in the ctDNA that facilitate GC management.

\section{CIRCULATING NON-CODING RNAS (ncRNAs)}

Deregulated ncRNAs expression has largely been reported in the literature acting as oncogene or with tumor suppressor role in several cancers types, including GC [61-63]. Since ncRNAs are important mediators of intracellular activities with tissue specific characteristics, quantification of deregulated ncRNAs expression in blood can indicate disease state, disease progression and/ or response to a particular treatment, therefore directing initial clinical practice. Secretion to the bloodstream is usually the results of cell death (necrosis or apoptosis) or due to active secretion from the cell, therefore, the expression profile reflects the primary tumor in the corresponding tissue [64].

A large number of studies have highlighted the potential importance of circulating ncRNAs as diagnostic, prognostic, and/or predictive biomarkers in cancer, mainly microRNAs (miRNAs) and long non-coding RNAs (lncRNAs). These molecules are remarkably stable as they are often incorporated into exosomes and microvesicles, thus providing resistance to RNase activity, extreme $\mathrm{pH}$ and multiple freeze-thaw cycles [62-63, 65-67].

\section{microRNAs}

miRNAs are a class of single-stranded small ncRNAs of 19-25 nucleotides (nt) in length that play an essential role in the negative post-transcriptional gene regulation of at least $50 \%$ of all protein-coding gene [64]. Supplementary Table 1 summarizes a large number of circulating miRNAs as potential diagnosis and prognosis biomarkers in GC and their clinical implications [68-88].

Recently, Tsai et al. [80] demonstrated that miR$196 \mathrm{a} / \mathrm{b}$ expression in the serum of GC patients could be more sensitive and specific for GC diagnosis than CA 19-9 (carcinoembryonic antigen 19-9) or CEA (carbohydrate antigen). Moreover, circulating miR-196a/b was also associated with TNM stage, a poor survival rate and cancer outcome, suggesting that $\mathrm{miR}-196 \mathrm{a} / \mathrm{b}$ is a potential diagnostic and prognostic biomarker in GC.

Several studies also described associations between miRNA expression, H. pylori and EBV infection, which are well-known causes of GC [61, 62]. For instance, Shiotani et al. [73] observed an association between upregulated circulating miR-21 and miR-106b and $H$. pylori infection. The authors also suggested that the upregulation of both miRNAs in the serum of patients after $H$. pylori eradication could be used for the detection of high risk GC in individuals with extensive atrophy.

A single candidate approach can reveal deregulated miRNA, however, the search for a miRNA signature profile that can predict prognosis and monitor cancer progression has been a common focus of many studies. Among these studies, it was reported that the miRNA profile in the serum/plasma of patients with GC displayed unique miRNA changes or a miRNAs signature.

Using MiSeq sequencing, Jiang et al. [89] performed an initial screening of serum miRNAs in ten GC patients with lymph node metastasis (LNM+), ten patients without lymph node metastasis (LNM-) and ten healthy controls. Then, the candidate miRNAs (miR-501-3p, miR-143-3p, miR451, and miR-146a) were validated in serum samples from 73 controls, 103 LNM+ and 103 LNM- patients by qRTPCR. Prediction of LNM+ in GC restricted to the mucosa prior to surgery with a circulating miRNA panel could help determine the need for surgical lymph node resection. This would allow endoscopic mucosal resection, a less invasive 
treatment, to be immediately conducted without delay to provide more effective treatment for early gastric tumors. On the other hand, endoscopic resection of tumors should be avoided when the miRNA panel to indicates LNM+. In the case, surgical resection with an extensive lymphadenectomy would be recommended for a better outcome in GC patients.

Despite numerous efforts, no consensus has been found for miRNA biomarkers that can be incorporated into GC clinical practice. For this occur, a number of obstacles must be overcome, for example, the quantification of miRNAs can suffer from variations due to inadequate processing, storage, RNA extraction, and reference genes choice for qRT-PCR quantification. Variation is such a problem that and even differences between serum and plasma miRNA quantification have been observed [86, 69, 90-93]. Moreover, there is no unique protocol to control for these parameters. Divergences in the analysis of the circulating miRNA make it difficult for perform a comparison among them.

\section{Long non-coding RNAs}

lncRNAs comprise a diverse class of RNA transcripts $>200 \mathrm{nt}$ in length. They regulate gene expression through a variety of transcriptional and posttranscriptional mechanisms, including i) chromatin modification and remodeling; ii) direct transcriptional regulation; iii) regulation of RNA processing events such as splicing, editing, localization, translation and turnover/ degradation; iv) induction of DNA methyltransferases; v) protein scaffolding; vi) modulation of miRNA regulation; vii) miRNA precursor processing; viii) regulation of translation; and ix) protein binding [94].

Similar to miRNAs, a number of circulating lncRNAs also have emerged as diagnostic and/or prognostic biomarkers in GC (Supplementary Table 2) [95-103]. For instance, HULC (highly up-regulated in liver cancer) was significantly higher in the serum of GC patients than healthy controls. Interestingly, the serum HULC level was significantly decreased in post-treatment patients to a level similar to that of healthy individuals. In addition, serum HULC levels expression was associated with tumor size, lymph node metastasis, distant metastasis and $H$. pylori, a strong risk factor for both GC development and progression. Furthermore, a ROC curve to evaluate the diagnostic utility of HULC revealed that serum HULC levels provides a more powerful differential ability than CEA and CA72-4, followup detection and Kaplan-Meier curve analysis showed that HULC is a good predictor of GC prognosis. Taken together, these findings indicate that HULC may be a potential tumor biomarker for early diagnosis, progression monitoring and GC prognosis of GC [100].

According to Chao et al. [104], elevated circulating levels of AA174084 were associated with invasion and lymph node metastasis in GC patients. Their levels dropped markedly on day 15 after surgery compared to preoperative levels. However, the measurement of plasma-based
AA174084 has obvious limitations, because AA174084 levels in plasma do not differ between healthy individuals and GC patients. Thus, the authors suggested that AA174084 may have potential as a prognostic biomarker for GC.

Several studies investigated the levels of circulating H19 (H19, imprinted maternally expressed transcript) from GC patients as potential diagnostic biomarker [96-98]. Arita et al. [96] found that H19 levels were significantly higher in the plasma of GC patients than in healthy controls. However, there was no correlation between plasma H19 levels and the clinicopathological factors of these GC patients. In comparison with the levels in pre- and postoperative paired plasma samples, H19 levels were significantly lower in postoperative plasma.

In 2015, Zhou et al. [97] validated the expression of eight lncRNAs (HOTAIR, CCAT1, PVT1, H19, MALAT1, MRUL, GHET1 and HULC) by test-scale analyses in tissue and plasma using qRT-PCR. Among them, H19 and another five lncRNAs (HOTAIR, PVT1, MALAT1, GHET1 and HULC) were significantly higher in tumor tissues compared to matched normal samples. Of these lncRNAs, only H19, MALAT1 and HOTAIR were significantly higher in the plasma of ten GC patients compared to ten healthy controls. Among these three lncRNAs, only H19 expression was significantly higher in GC patient plasma compared to heathy controls, when plasma lncRNAs levels were examined on a large scale using plasma from $70 \mathrm{GC}$ patients and 70 healthy controls. That analysis involved the comparison of plasma H19 concentrations in paired plasma obtained from pre- and postoperative samples; H19 levels were significantly reduced postoperatively in patients with high preoperative plasma H19. Clearly, these findings demonstrated that plasma levels of H19 are useful as a potential biomarker for the diagnosis of GC, particularly for early tumor screening.

Many of the obstacles that exist for the effective application of circulating lncRNAs in GC clinical practice are similar to those described for circulating miRNAs.

\section{FUTURE DIRECTIONS}

Liquid biopsy approaches have enormous implications for cancer, ranging from early diagnosis to the monitoring of treatment response, and have transformed clinical care. Currently, the liquid biopsy does not replace the conventional biopsy, however, it has been applied to tumor growth control and in deciding on therapeutic choice to improve the overall survival rate of patient with different cancer types. Nevertheless, liquid biopsies remain removed from GC clinical management. Figure 1 summarizes the putative outlook of liquid biopsy use and their potential application in clinical care in GC management (classified as strong, moderate and weak evidence).

In GC, we believe that the earliest use of liquid biopsy in clinical practice should focus on therapies that target detection 
and monitoring. Indeed, HER2 status in CTCs or ctDNA has emerged as a therapeutic marker of effective molecular targeted therapy and therapeutic response monitoring in GC patients [14, 56, 57]. Figure 2 shows timeline of CTC and ctDNA analysis in pre-treatment and post-treatment (immediately and monitoring) period of GC patients.

Before liquid biopsies are incorporated into clinical practice as a precision medicine tool to drive GC management, pre-analytical steps must be standardized in order to ensure reproducible processing techniques. Moreover, analytical steps must be validated, such as the enumeration of CTCs and ctDNA, the quantification of circulating ncRNAs, subsequent CTCs characterization and genetic or epigenetic alterations in ctDNA analysis. Finally, CTCs markers or assays applied to circulating ncRNAs or ctDNA measurements must have strong and reproducible sensitivity and specificity, beyond having the suitable internal and external quality controls.

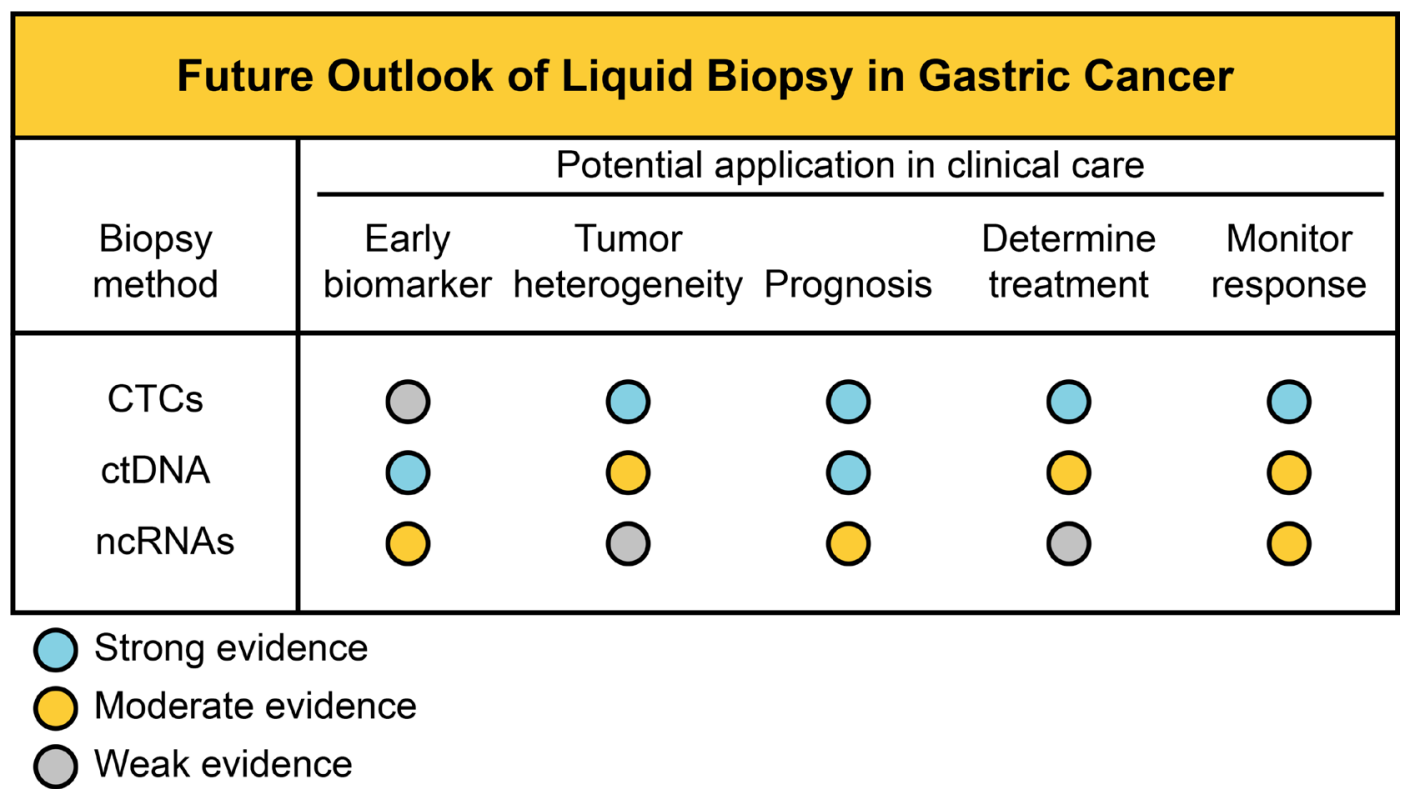

Figure 1: Potential application of liquid biopsies in GC management. Establishment of standard analysis of CTCs, ctDNA and circulating ncRNAs in the future.

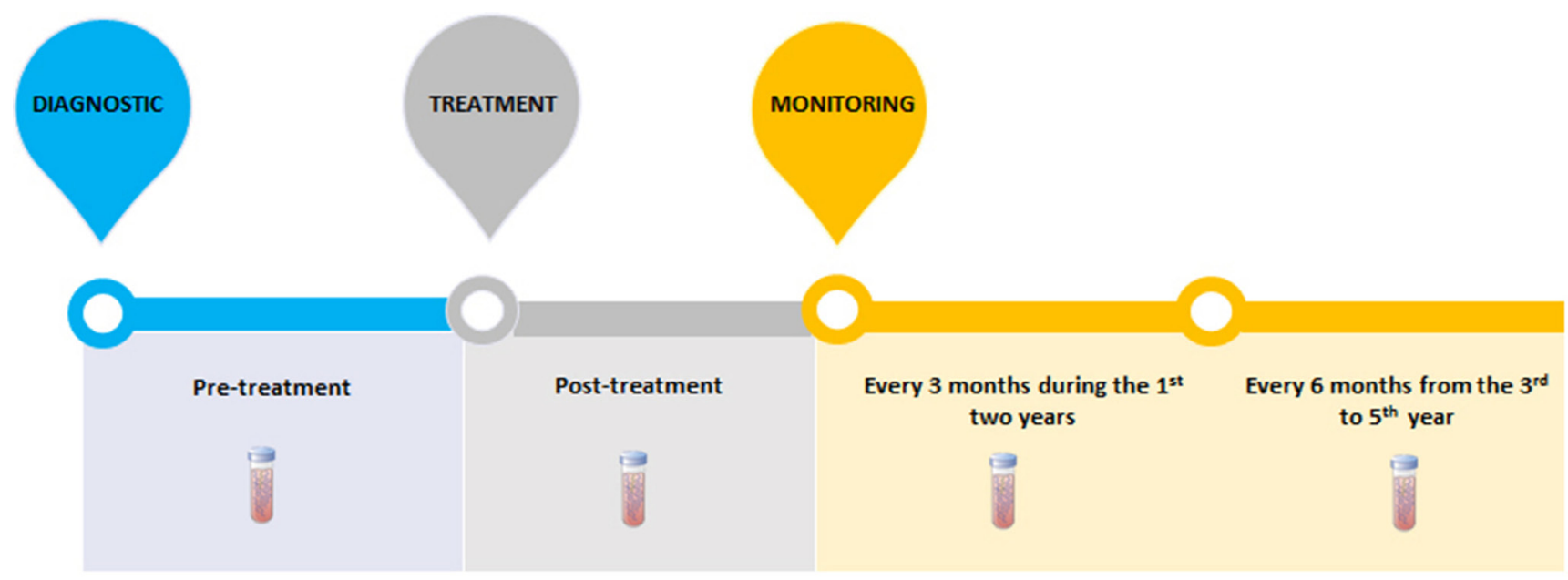

LIQUID BIOPSY TIMELINE

Figure 2: Liquid biopsies timeline. At the diagnostic, the pretreatment ctDNA demonstrates the molecular characteristics of the tumor, as well as the patient's prognosis. After treatment, ctDNA quantification could measure the treatment's efficacy, since ctDNA bloodstream half-time is about 1-2.4hours. In case of advanced gastric tumors, CTCs analysis could also be used in the same manner. Moreover, monitoring of ctDNA or CTCs, every three months during the first two years and every six months from the third to fifth year, could evaluate therapeutic response and recurrence disease before the patients shows clinical symptoms or metastasis is observed by computed tomography. 
Consequently, many questions remain about liquid biopsies from blood that require resolution: i) how should the blood samples be collected to ensure quality biomarker detection; ii) which is the ideal method and marker for CTC enumeration and characterization; iii) what gene alterations are key for ctDNA measurement; iv) what reference genes are stable and suitable for circulating ncRNA measurement in GC patients; v) what criteria should be adopted for the CTC, ctDNA and circulating ncRNA validation analysis.

\section{CONFLICTS OF INTEREST}

None.

\section{REFERENCES}

1. Ferlay J, Soerjomataram I, Dikshit R, Eser S, Mathers C, Rebelo M, Parkin DM, Forman D, Bray F. Cancer incidence and mortality worldwide: sources, methods and major patterns in GLOBOCAN 2012. Int J Cancer. 2015; 136:E359-86. https://doi.org/10.1002/ijc.29210.

2. Pasechnikov V, Chukov S, Fedorov E, Kikuste I, Leja M. Gastric cancer: prevention, screening and early diagnosis. World J Gastroenterol. 2014; 20:13842-62. https://doi. org/10.3748/wjg.v20.i38.13842.

3. Levy I, Gralnek IM. Complications of diagnostic colonoscopy, upper endoscopy, and enteroscopy. Best Pract Res Clin Gastroenterol. 2016; 30:705-18. https://doi. org/10.1016/j.bpg.2016.09.005.

4. Gupta N, Bansal A, Wani SB, Gaddam S, Rastogi A, Sharma P. Endoscopy for upper GI cancer screening in the general population: a cost-utility analysis. Gastrointest Endosc. 2011; 74:610-624.e2. https://doi.org/10.1016/j. gie.2011.05.001.

5. Gerlinger M, Rowan AJ, Horswell S, Math M, Larkin J, Endesfelder D, Gronroos E, Martinez P, Matthews N, Stewart A, Tarpey P, Varela I, Phillimore B, et al. Intratumor heterogeneity and branched evolution revealed by multiregion sequencing. N Engl J Med. 2012; 366:88392. https://doi.org/10.1056/NEJMoa1113205.

6. Siravegna G, Marsoni S, Siena S, Bardelli A. Integrating liquid biopsies into the management of cancer. Nat Rev Clin Oncol. 2017; 14:531-48. https://doi.org/10.1038/ nrclinonc.2017.14.

7. Pantel K, Alix-Panabières C. Liquid biopsy in 2016: circulating tumour cells and cell-free DNA in gastrointestinal cancer. Nat Rev Gastroenterol Hepatol. 2017; 14:73-74. https://doi.org/10.1038/nrgastro.2016.198.

8. Wu CH, Lin SR, Yu FJ, Wu DC, Pan YS, Hsieh JS, Huang SY, Wang JY. Development of a high-throughput membrane-array method for molecular diagnosis of circulating tumor cells in patients with gastric cancers. Int J Cancer. 2006; 119:373-79. https://doi.org/10.1002/ ijc. 21856 .
9. Hiraiwa K, Takeuchi H, Hasegawa H, Saikawa Y, Suda $\mathrm{K}$, Ando T, Kumagai K, Irino T, Yoshikawa T, Matsuda S, Kitajima M, Kitagawa Y. Clinical significance of circulating tumor cells in blood from patients with gastrointestinal cancers. Ann Surg Oncol. 2008; 15:3092-100. https://doi. org/10.1245/s10434-008-0122-9.

10. Bertazza L, Mocellin S, Marchet A, Pilati P, Gabrieli J, Scalerta R, Nitti D. Survivin gene levels in the peripheral blood of patients with gastric cancer independently predict survival. J Transl Med. 2009; 7:111. https://doi. org/10.1186/1479-5876-7-111.

11. Matsusaka S, Chìn K, Ogura M, Suenaga M, Shinozaki E, Mishima Y, Terui Y, Mizunuma N, Hatake K. Circulating tumor cells as a surrogate marker for determining response to chemotherapy in patients with advanced gastric cancer. Cancer Sci. 2010; 101:1067-71. https://doi.org/10.1111/ j.1349-7006.2010.01492.x.

12. Cui L, Lou Y, Zhang X, Zhou H, Deng H, Song H, Yu X, Xiao B, Wang W, Guo J. Detection of circulating tumor cells in peripheral blood from patients with gastric cancer using piRNAs as markers. Clin Biochem. 2011; 44:105057. https://doi.org/10.1016/j.clinbiochem.2011.06.004.

13. Uenosono Y, Arigami T, Kozono T, Yanagita S, Hagihara T, Haraguchi N, Matsushita D, Hirata M, Arima H, Funasako Y, Kijima Y, Nakajo A, Okumura H, et al. Clinical significance of circulating tumor cells in peripheral blood from patients with gastric cancer. Cancer. 2013; 119:398491. https://doi.org/10.1002/cncr.28309.

14. Iwatsuki $\mathrm{M}$, Toyoshima $\mathrm{K}$, Watanabe $\mathrm{M}$, Hayashi $\mathrm{N}$, Ishimoto T, Eto K, Iwagami S, Baba Y, Yoshida N, Hayashi A, Ohta Y, Baba H. Frequency of HER2 expression of circulating tumour cells in patients with metastatic or recurrent gastrointestinal cancer. Br J Cancer. 2013; 109:2829-32. https://doi.org/10.1038/bjc.2013.680.

15. Yuan D, Chen L, Li M, Xia H, Zhang Y, Chen T, Xia R, Tang Q, Gao F, Mo X, Liu M, Bi F. Isolation and characterization of circulating tumor cells from human gastric cancer patients. J Cancer Res Clin Oncol. 2015; 141:647-60. https://doi.org/10.1007/s00432-014-1814-0.

16. Li TT, Liu H, Li FP, Hu YF, Mou TY, Lin T, Yu J, Zheng L, Li GX. Evaluation of epithelial-mesenchymal transitioned circulating tumor cells in patients with resectable gastric cancer: relevance to therapy response. World J Gastroenterol. 2015; 21:13259-67. https://doi.org/10.3748/wjg.v21.i47.13259.

17. Ma J, Yao S, Li XS, Kang HR, Yao FF, Du N. Neoadjuvant Therapy of DOF Regimen Plus Bevacizumab Can Increase Surgical Resection Ratein Locally Advanced Gastric Cancer: A Randomized, Controlled Study. Medicine (Baltimore). 2015; 94:e1489. https://doi.org/10.1097/ MD.0000000000001489.

18. Kubisch I, de Albuquerque A, Schuppan D, Kaul S, Schaich M, Stölzel U. Prognostic Role of a Multimarker Analysis of Circulating Tumor Cells in Advanced Gastric and Gastroesophageal Adenocarcinomas. Oncology. 2015; 89:294-303. https://doi.org/10.1159/000437373. 
19. Xia P, Song CL, Liu JF, Wang D, Xu XY. Prognostic value of circulating CD133(+) cells in patients with gastric cancer. Cell Prolif. 2015; 48:311-17. https://doi.org/10.1111/ cpr.12175.

20. Toyoshima K, Hayashi A, Kashiwagi M, Hayashi N, Iwatsuki M, Ishimoto T, Baba Y, Baba H, Ohta Y. Analysis of circulating tumor cells derived from advanced gastric cancer. Int J Cancer. 2015; 137:991-98. https://doi. org/10.1002/ijc.29455.

21. Okabe H, Tsunoda S, Hosogi H, Hisamori S, Tanaka E, Tanaka S, Sakai Y. Circulating Tumor Cells as an Independent Predictor of Survival in Advanced Gastric Cancer. Ann Surg Oncol. 2015; 22:3954-61. https://doi. org/10.1245/s10434-015-4483-6.

22. Ito H, Yamaguchi N, Onimaru M, Kimura S, Ohmori T, Ishikawa F, Sato J, Ito S, Inoue H. Change in number and size of circulating tumor cells with high telomerase activity during treatment of patients with gastric cancer. Oncol Lett. 2016; 12:4720-26. https://doi.org/10.3892/ol.2016.5239.

23. Li Y, Zhang X, Gong J, Zhang Q, Gao J, Cao Y, Wang DD, Lin PP, Shen L. Aneuploidy of chromosome 8 in circulating tumor cells correlates with prognosis in patients with advanced gastric cancer. Chin J Cancer Res. 2016; 28:57988. https://doi.org/10.21147/j.issn.1000-9604.2016.06.04.

24. Kolostova K, Matkowski R, Gürlich R, Grabowski K, Soter K, Lischke R, Schützner J, Bobek V. Detection and cultivation of circulating tumor cells in gastric cancer. Cytotechnology. 2016; 68:1095-102. https://doi. org/10.1007/s10616-015-9866-9.

25. Li Y, Gong J, Zhang Q, Lu Z, Gao J, Li Y, Cao Y, Shen L. Dynamic monitoring of circulating tumour cells to evaluate therapeutic efficacy in advanced gastric cancer. Br J Cancer. 2016; 114:138-45. https://doi.org/10.1038/bjc.2015.417.

26. Zhang T, Boominathan R, Foulk B, Rao C, Kemeny G, Strickler JH, Abbruzzese JL, Harrison MR, Hsu DS, Healy P, Li J, Pi C, Prendergast KM, et al. Development of a Novel c-MET-Based CTC Detection Platform. Mol Cancer Res. 2016; 14:539-47. https://doi.org/10.1158/1541-7786.MCR-16-0011.

27. Kang HM, Kim GH, Jeon HK, Kim DH, Jeon TY, Park DY, Jeong H, Chun WJ, Kim MH, Park J, Lim M, Kim TH, Cho YK. Circulating tumor cells detected by lab-on-a-disc: role in early diagnosis of gastric cancer. PLoS One. 2017; 12:e0180251. https://doi.org/10.1371/journal.pone.0180251.

28. Zheng X, Fan L, Zhou P, Ma H, Huang S, Yu D, Zhao L, Yang S, Liu J, Huang A, Cai C, Dai X, Zhang T. Detection of Circulating Tumor Cells and Circulating Tumor Microemboli in Gastric Cancer. Transl Oncol. 2017; 10:431-41. https://doi.org/10.1016/j.tranon.2017.02.007.

29. Mishima Y, Matsusaka S, Chin K, Mikuniya M, Minowa S, Takayama T, Shibata H, Kuniyoshi R, Ogura M, Terui Y, Mizunuma N, Hatake K. Detection of HER2 Amplification in Circulating Tumor Cells of HER2-Negative Gastric Cancer Patients. Target Oncol. 2017; 12:341-51. https:// doi.org/10.1007/s11523-017-0493-6.
30. Dharmasiri U, Witek MA, Adams AA, Soper SA. Microsystems for the capture of low-abundance cells. Annu Rev Anal Chem (Palo Alto, Calif). 2010; 3:409-31. https:// doi.org/10.1146/annurev.anchem.111808.073610.

31. Harris L, Fritsche H, Mennel R, Norton L, Ravdin P, Taube S, Somerfield MR, Hayes DF, Bast RC Jr, and American Society of Clinical Oncology. American Society of Clinical Oncology 2007 update of recommendations for the use of tumor markers in breast cancer. J Clin Oncol. 2007; 25:5287-312. https://doi.org/10.1200/JCO.2007.14.2364.

32. van de Stolpe A, Pantel K, Sleijfer S, Terstappen LW, den Toonder JM. Circulating tumor cell isolation and diagnostics: toward routine clinical use. Cancer Res. 2011; 71:5955-60. https://doi.org/10.1158/0008-5472.CAN-11-1254.

33. Allard WJ, Matera J, Miller MC, Repollet M, Connelly MC, Rao C, Tibbe AG, Uhr JW, Terstappen LW. Tumor cells circulate in the peripheral blood of all major carcinomas but not in healthy subjects or patients with nonmalignant diseases. Clin Cancer Res. 2004; 10:6897-904. https://doi. org/10.1158/1078-0432.CCR-04-0378.

34. Guan X, Ma F, Liu S, Wu S, Xiao R, Yuan L, Sun X, Yi Z, Yang $\mathrm{H}, \mathrm{Xu}$ B. Analysis of the hormone receptor status of circulating tumor cell subpopulations based on epithelialmesenchymal transition: a proof-of-principle study on the heterogeneity of circulating tumor cells. Oncotarget. 2016; 7:65993-6002. https://doi.org/10.18632/oncotarget.11787.

35. Friedlander TW, Premasekharan G, Paris PL. Looking back, to the future of circulating tumor cells. Pharmacol Ther. 2014; 142:271-80. https://doi.org/10.1016/j. pharmthera.2013.12.011.

36. Mikolajczyk SD, Millar LS, Tsinberg P, Coutts SM, Zomorrodi M, Pham T, Bischoff FZ, Pircher TJ. Detection of EpCAM-Negative and Cytokeratin-Negative Circulating Tumor Cells in Peripheral Blood. J Oncol. 2011; 2011:252361. https://doi.org/10.1155/2011/252361.

37. Ferreira MM, Ramani VC, Jeffrey SS. Circulating tumor cell technologies. Mol Oncol. 2016; 10:374-94. https://doi. org/10.1016/j.molonc.2016.01.007.

38. Liu H, Zhang X, Li J, Sun B, Qian H, Yin Z. The biological and clinical importance of epithelial-mesenchymal transition in circulating tumor cells. J Cancer Res Clin Oncol. 2015; 141:189-201. https://doi.org/10.1007/s00432-014-1752-x.

39. Adams DL, Stefansson S, Haudenschild C, Martin SS, Charpentier M, Chumsri S, Cristofanilli M, Tang CM, Alpaugh RK. Cytometric characterization of circulating tumor cells captured by microfiltration and their correlation to the CellSearch(®) CTC test. Cytometry A. 2015; 87:13744. https://doi.org/10.1002/cyto.a.22613.

40. Parkinson DR, Dracopoli N, Petty BG, Compton C, Cristofanilli M, Deisseroth A, Hayes DF, Kapke G, Kumar P, Lee JS, Liu MC, McCormack R, Mikulski S, et al. Considerations in the development of circulating tumor cell technology for clinical use. J Transl Med. 2012; 10:138. https://doi.org/10.1186/1479-5876-10-138. 
41. Li Y, Zhang X, Ge S, Gao J, Gong J, Lu M, Zhang Q, Cao Y, Wang DD, Lin PP, Shen L. Clinical significance of phenotyping and karyotyping of circulating tumor cells in patients with advanced gastric cancer. Oncotarget. 2014; 5:6594-602. https://doi.org/10.18632/oncotarget.2175.

42. Calcagno DQ, Leal MF, Taken SS, Assumpção PP, Demachki S, Smith MA, Burbano RR. Aneuploidy of chromosome 8 and C-MYC amplification in individuals from northern Brazil with gastric adenocarcinoma. Anticancer Res. 2005; 25:4069-74.

43. Calcagno DQ, Leal MF, Seabra AD, Khayat AS, Chen ES, Demachki S, Assumpção PP, Faria MH, Rabenhorst SH, Ferreira MV, de Arruda Cardoso Smith M, Burbano RR. Interrelationship between chromosome 8 aneuploidy, C-MYC amplification and increased expression in individuals from northern Brazil with gastric adenocarcinoma. World J Gastroenterol. 2006; 12:6207-11. https://doi.org/10.3748/wjg.v12.i38.6207.

44. Calcagno DQ, Guimarães AC, Leal MF, Seabra AD, Khayat AS, Pontes TB, Assumpção PP, De Arruda Cardoso Smith M, Burbano RR. MYC insertions in diffuse-type gastric adenocarcinoma. Anticancer Res. 2009; 29:2479-83.

45. Assumpção PP, Ishak G, Chen ES, Takeno SS, Leal MF, Guimarães AC, Calcagno DQ, Khayat AS, Demachki S, Smith MA, Burbano RR. Numerical aberrations of chromosome 8 detected by conventional cytogenetics and fluorescence in situ hybridization in individuals from northern Brazil with gastric adenocarcinoma. Cancer Genet Cytogenet. 2006; 169:45-49. https://doi.org/10.1016/j. cancergencyto.2006.03.019.

46. Leal MF, Martins do Nascimento JL, da Silva CE, Vita Lamarão MF, Calcagno DQ, Khayat AS, Assumpção PP, Cabral IR, de Arruda Cardoso Smith M, Burbano RR. Establishment and conventional cytogenetic characterization of three gastric cancer cell lines. Cancer Genet Cytogenet. 2009; 195:85-91. https://doi. org/10.1016/j.cancergencyto.2009.04.020.

47. Burbano RR, Assumpção PP, Leal MF, Calcagno DQ, Guimarães AC, Khayat AS, Takeno SS, Chen ES, De Arruda Cardoso Smith M. C-MYC locus amplification as metastasis predictor in intestinal-type gastric adenocarcinomas: CGH study in Brazil. Anticancer Res. 2006; 26:2909-14.

48. Hou JM, Krebs M, Ward T, Sloane R, Priest L, Hughes A, Clack G, Ranson M, Blackhall F, Dive C. Circulating tumor cells as a window on metastasis biology in lung cancer. Am J Pathol. 2011; 178:989-96. https://doi.org/10.1016/j. ajpath.2010.12.003.

49. Chinen LT, Abdallah EA, Braun AC, Flores BC, Corassa M, Sanches SM, Fanelli MF. Circulating Tumor Cells as Cancer Biomarkers in the Clinic. Adv Exp Med Biol. 2017; 994:1-41. https://doi.org/10.1007/978-3-319-55947-6_1.

50. Pietrasz D, Pécuchet N, Fabre E, Blons H, Chevalier L, Taly V, Laurent-Puig P, Bachet JB. [What future for circulating tumor DNA? Current data and prospects in colorectal, non- small cell lung and pancreatic cancers]. [Article in French]. Bull Cancer. 2016; 103:55-65. https://doi.org/10.1016/j. bulcan.2015.10.017.

51. Siravegna G, Mussolin B, Buscarino M, Corti G, Cassingena A, Crisafulli G, Ponzetti A, Cremolini C, Amatu A, Lauricella C, Lamba S, Hobor S, Avallone A, et al. Clonal evolution and resistance to EGFR blockade in the blood of colorectal cancer patients. Nat Med. 2015; 21:827. https://doi.org/10.1038/nm0715-827b.

52. Tang JC, Feng YL, Guo T, Xie AY, Cai XJ. Circulating tumor DNA in hepatocellular carcinoma: trends and challenges. Cell Biosci. 2016; 6:32. https://doi.org/10.1186/ s13578-016-0100-z.

53. Hamakawa T, Kukita Y, Kurokawa Y, Miyazaki Y, Takahashi T, Yamasaki M, Miyata H, Nakajima K, Taniguchi K, Takiguchi S, Mori M, Doki Y, Kato K. Monitoring gastric cancer progression with circulating tumour DNA. Br J Cancer. 2015; 112:352-56. https://doi. org/10.1038/bjc.2014.609.

54. Fang WL, Lan YT, Huang KH, Liu CA, Hung YP, Lin CH, Jhang FY, Chang SC, Chen MH, Chao Y, Lin WC, Lo SS, Fen-Yau Li A, et al. Clinical significance of circulating plasma DNA in gastric cancer. Int J Cancer. 2016; 138:2974-83. https://doi.org/10.1002/ijc.30018.

55. Shoda K, Masuda K, Ichikawa D, Arita T, Miyakami Y, Watanabe M, Konishi H, Imoto I, Otsuji E. HER2 amplification detected in the circulating DNA of patients with gastric cancer: a retrospective pilot study. Gastric Cancer. 2015; 18:698-710. https://doi.org/10.1007/s10120014-0432-5.

56. Shoda K, Ichikawa D, Fujita Y, Masuda K, Hiramoto H, Hamada J, Arita T, Konishi H, Komatsu S, Shiozaki A, Kakihara N, Okamoto K, Taniguchi H, et al. Monitoring the HER2 copy number status in circulating tumor DNA by droplet digital PCR in patients with gastric cancer. Gastric Cancer. 2017; 20:126-35. https://doi.org/10.1007/s10120-016-0599-z.

57. Gao Y, Zhang K, Xi H, Cai A, Wu X, Cui J, Li J, Qiao Z, Wei B, Chen L. Diagnostic and prognostic value of circulating tumor DNA in gastric cancer: a meta-analysis. Oncotarget. 2017; 8:6330-40. https://doi.org/10.18632/ oncotarget.14064.

58. Du J, Wu X, Tong X, Wang X, Wei J, Yang Y, Chang Z, Mao Y, Shao YW, Liu B. Circulating tumor DNA profiling by next generation sequencing reveals heterogeneity of crizotinib resistance mechanisms in a gastric cancer patient with MET amplification. Oncotarget. 2017; 8:26281-87. https://doi.org/10.18632/oncotarget.15457.

59. Lennerz JK, Kwak EL, Ackerman A, Michael M, Fox SB, Bergethon K, Lauwers GY, Christensen JG, Wilner KD, Haber DA, Salgia R, Bang YJ, Clark JW, et al. MET amplification identifies a small and aggressive subgroup of esophagogastric adenocarcinoma with evidence of responsiveness to crizotinib. J Clin Oncol. 2011; 29:480310. https://doi.org/10.1200/JCO.2011.35.4928. 
60. Kwak EL, Ahronian LG, Siravegna G, Mussolin B, Godfrey JT, Clark JW, Blaszkowsky LS, Ryan DP, Lennerz JK, Iafrate AJ, Bardelli A, Hong TS, Corcoran RB. Molecular Heterogeneity and Receptor Coamplification Drive Resistance to Targeted Therapy in MET-Amplified Esophagogastric Cancer. Cancer Discov. 2015; 5:1271-81. https://doi.org/10.1158/2159-8290.CD-15-0748.

61. Calcagno DQ, de Arruda Cardoso Smith M, Burbano RR. Cancer type-specific epigenetic changes: gastric cancer. Methods Mol Biol. 2015; 1238:79-101. https://doi. org/10.1007/978-1-4939-1804-1_5.

62. Ferreira Martins NN, da Silva Oliveira KC, Braga Bona A, de Arruda Cardoso Smith M, Ishak G, Assumpção PP, Burbano RR, Calcagno DQ. The Emerging Role of miRNAs and Their Clinical Implication in Biliary Tract Cancer. Gastroenterol Res Pract. 2016; 2016:9797410. https://doi.org/10.1155/2016/9797410.

63. da Silva Oliveira KC, Thomaz Araújo TM, Albuquerque CI, Barata GA, Gigek CO, Leal MF, Wisnieski F, Rodrigues Mello Junior FA, Khayat AS, de Assumpção PP, Rodriguez Burbano RM, Smith MC, Calcagno DQ. Role of miRNAs and their potential to be useful as diagnostic and prognostic biomarkers in gastric cancer. World J Gastroenterol. 2016; 22:7951-62. https://doi.org/10.3748/wjg.v22.i35.7951.

64. Schwarzenbach H, Nishida N, Calin GA, Pantel K. Clinical relevance of circulating cell-free microRNAs in cancer. Nat Rev Clin Oncol. 2014; 11:145-56. https://doi.org/10.1038/ nrclinonc.2014.5.

65. Qi P, Zhou XY, Du X. Circulating long non-coding RNAs in cancer: current status and future perspectives. Mol Cancer. 2016; 15:39. https://doi.org/10.1186/s12943-016-0524-4.

66. Khan A, Shah S, Wahid F, Khan FG, Jabeen S. Identification of microRNA precursors using reduced and hybrid features. Mol Biosyst. 2017; 13:1640-45. https://doi.org/10.1039/ C7MB00115K.

67. Padmanabhan N, Ushijima T, Tan P. How to stomach an epigenetic insult: the gastric cancer epigenome. Nat Rev Gastroenterol Hepatol. 2017; 14:467-78.

68. Huang Z, Zhu D, Wu L, He M, Zhou X, Zhang L, Zhang H, Wang W, Zhu J, Cheng W, Chen Y, Fan Y, Qi L, et al. Six Serum-Based miRNAs as Potential Diagnostic Biomarkers for Gastric Cancer. Cancer Epidemiol Biomarkers Prev. 2017; 26:188-96. https://doi.org/10.1158/1055-9965.EPI16-0607.

69. Wang H, Wang L, Wu Z, Sun R, Jin H, Ma J, Liu L, Ling R, Yi J, Wang L, Bian J, Chen J, Li N, et al. Three dysregulated microRNAs in serum as novel biomarkers for gastric cancer screening. Med Oncol. 2014; 31:298. https://doi. org/10.1007/s12032-014-0298-8.

70. Zhou H, Guo JM, Lou YR, Zhang XJ, Zhong FD, Jiang Z, Cheng J, Xiao BX. Detection of circulating tumor cells in peripheral blood from patients with gastric cancer using microRNA as a marker. J Mol Med (Berl). 2010; 88:70917. https://doi.org/10.1007/s00109-010-0617-2.
71. Sierzega M, Kaczor M, Kolodziejczyk P, Kulig J, Sanak M, Richter P. Evaluation of serum microRNA biomarkers for gastric cancer based on blood and tissue pools profiling: the importance of miR-21 and miR-331. Br J Cancer. 2017; 117:266-273. https://doi.org/10.1038/bjc.2017.190.

72. Yang R, Fu Y, Zeng Y, Xiang M, Yin Y, Li L, Xu H, Zhong J, Zeng X. Serum miR-20a is a promising biomarker for gastric cancer. Biomed Rep. 2017; 6:429-34. https://doi. org/10.3892/br.2017.862.

73. Shiotani A, Murao T, Kimura Y, Matsumoto H, Kamada T, Kusunoki H, Inoue K, Uedo N, Iishi H, Haruma K. Identification of serum miRNAs as novel non-invasive biomarkers for detection of high risk for early gastric cancer. Br J Cancer. 2013; 109:2323-30. https://doi. org/10.1038/bjc.2013.596.

74. Zhang R, Wang W, Li F, Zhang H, Liu J. MicroRNA$106 \mathrm{~b} 25$ expressions in tumor tissues and plasma of patients with gastric cancers. Med Oncol. 2014; 31:243. https://doi.org/10.1007/s12032-014-0243-X.

75. Qiu X, Zhang J, Shi W, Liu S, Kang M, Chu H, Wu D, Tong N, Gong W, Tao G, Zhao Q, Qiang F, Zhu H, et al. Circulating MicroRNA-26a in Plasma and Its Potential Diagnostic Value in Gastric Cancer. PLoS One. 2016; 11:e0151345. https://doi.org/10.1371/journal.pone.0151345.

76. Liu R, Zhang C, Hu Z, Li G, Wang C, Yang C, Huang D, Chen X, Zhang H, Zhuang R, Deng T, Liu H, Yin J, et al. A five-microRNA signature identified from genomewide serum microRNA expression profiling serves as a fingerprint for gastric cancer diagnosis. Eur J Cancer. 2011; 47:784-91. https://doi.org/10.1016/j.ejca.2010.10.025.

77. Chen Q, Ge X, Zhang Y, Xia H, Yuan D, Tang Q, Chen L, Pang X, Leng W, Bi F. Plasma miR-122 and miR-192 as potential novel biomarkers for the early detection of distant metastasis of gastric cancer. Oncol Rep. 2014; 31:1863-70. https://doi.org/10.3892/or.2014.3004.

78. Kim SY, Jeon TY, Choi CI, Kim DH, Kim DH, Kim GH, Ryu DY, Lee BE, Kim HH. Validation of circulating miRNA biomarkers for predicting lymph node metastasis in gastric cancer. J Mol Diagn. 2013; 15:661-69. https://doi. org/10.1016/j.jmoldx.2013.04.004.

79. Gorur A, Balci Fidanci S, Dogruer Unal N, Ayaz L, Akbayir S, Yildirim Yaroglu H, Dirlik M, Serin MS, Tamer L. Determination of plasma microRNA for early detection of gastric cancer. Mol Biol Rep. 2013; 40:2091-96. https://doi. org/10.1007/s11033-012-2267-7.

80. Tsai MM, Wang CS, Tsai CY, Huang CG, Lee KF, Huang HW, Lin YH, Chi HC, Kuo LM, Lu PH, Lin KH. Circulating microRNA-196a/b are novel biomarkers associated with metastatic gastric cancer. Eur J Cancer. 2016; 64:137-48. https://doi.org/10.1016/j.ejca.2016.05.007.

81. Li C, Li JF, Cai Q, Qiu QQ, Yan M, Liu BY, Zhu ZG. MiRNA-199a-3p: A potential circulating diagnostic biomarker for early gastric cancer. J Surg Oncol. 2013; 108:89-92. https://doi.org/10.1002/jso.23358. 
82. Valladares-Ayerbes M, Reboredo M, Medina-Villaamil V, Iglesias-Díaz P, Lorenzo-Patiño MJ, Haz M, Santamarina I, Blanco M, Fernández-Tajes J, Quindós M, Carral A, Figueroa A, Antón-Aparicio LM, Calvo L. Circulating miR-200c as a diagnostic and prognostic biomarker for gastric cancer. J Transl Med. 2012; 10:186. https://doi. org/10.1186/1479-5876-10-186.

83. Imaoka H, Toiyama Y, Okigami M, Yasuda H, Saigusa S, Ohi M, Tanaka K, Inoue Y, Mohri Y, Kusunoki M. Circulating microRNA-203 predicts metastases, early recurrence, and poor prognosis in human gastric cancer. Gastric Cancer. 2016; 19:744-53. https://doi.org/10.1007/ s10120-015-0521-0.

84. Zhang WH, Gui JH, Wang CZ, Chang Q, Xu SP, Cai CH, Li YN, Tian YP, Yan L, Wu B. The identification of miR-375 as a potential biomarker in distal gastric adenocarcinoma. Oncol Res. 2012; 20:139-47. https://doi.org/10.3727/0965 $04012 X 13522227232156$.

85. Song MY, Pan KF, Su HJ, Zhang L, Ma JL, Li JY, Yuasa Y, Kang D, Kim YS, You WC. Identification of serum microRNAs as novel non-invasive biomarkers for early detection of gastric cancer. PLoS One. 2012; 7:e33608. https://doi.org/10.1371/journal.pone.0033608.

86. Wu J, Li G, Yao Y, Wang Z, Sun W, Wang J. MicroRNA-421 is a new potential diagnosis biomarker with higher sensitivity and specificity than carcinoembryonic antigen and cancer antigen 125 in gastric cancer. Biomarkers. 2015; 20:58-63. https://doi.org/10.3109/1354750X.2014.992812.

87. Shin VY, Ng EK, Chan VW, Kwong A, Chu KM. A threemiRNA signature as promising non-invasive diagnostic marker for gastric cancer. Mol Cancer. 2015; 14:202. https://doi.org/10.1186/s12943-015-0473-3.

88. Liu X, Kwong A, Sihoe A, Chu KM. Plasma miR-940 may serve as a novel biomarker for gastric cancer. Tumour Biol. 2016; 37:3589-97. https://doi.org/10.1007/s13277-0154019-5.

89. Jiang X, Wang W, Yang Y, Du L, Yang X, Wang L, Zheng G, Duan W, Wang R, Zhang X, Wang L, Chen X, Wang C. Identification of circulating microRNA signatures as potential noninvasive biomarkers for prediction and prognosis of lymph node metastasis in gastric cancer. Oncotarget. 2017; 8:65132-42. https://doi.org/10.18632/ oncotarget.17789.

90. Hu J, Wang Z, Liao BY, Yu L, Gao X, Lu S, Wang S, Dai Z, Zhang X, Chen Q, Qiu SJ, Wu Y, Zhu H, et al. Human miR1228 as a stable endogenous control for the quantification of circulating microRNAs in cancer patients. Int J Cancer. 2014; 135:1187-94. https://doi.org/10.1002/ijc.28757.

91. Song J, Bai Z, Han W, Zhang J, Meng H, Bi J, Ma X, Han S, Zhang Z. Identification of suitable reference genes for qPCR analysis of serum microRNA in gastric cancer patients. Dig Dis Sci. 2012; 57:897-904. https://doi. org/10.1007/s10620-011-1981-7.

92. Xiang M, Zeng Y, Yang R, Xu H, Chen Z, Zhong J, Xie $\mathrm{H}, \mathrm{Xu} \mathrm{Y}$, Zeng X. U6 is not a suitable endogenous control for the quantification of circulating microRNAs. Biochem Biophys Res Commun. 2014; 454:210-14. https:/doi. org/10.1016/j.bbrc.2014.10.064.

93. Zhang Y, Zeng CJ, He L, Ding L, Tang KY, Peng WP. Selection of endogenous reference microRNA genes for quantitative reverse transcription polymerase chain reaction studies of boar spermatozoa cryopreservation. Theriogenology. 2015; 83:634-41. https://doi.org/10.1016/j. theriogenology.2014.10.027.

94. Melissari MT, Grote P. Roles for long non-coding RNAs in physiology and disease. Pflugers Arch. 2016; 468:945-58. https://doi.org/10.1007/s00424-016-1804-y.

95. Shao Y, Ye M, Jiang X, Sun W, Ding X, Liu Z, Ye G, Zhang $\mathrm{X}$, Xiao B, Guo J. Gastric juice long noncoding RNA used as a tumor marker for screening gastric cancer. Cancer. 2014; 120:3320-28. https://doi.org/10.1002/cncr.28882.

96. Arita T, Ichikawa D, Konishi H, Komatsu S, Shiozaki A, Shoda K, Kawaguchi T, Hirajima S, Nagata H, Kubota T, Fujiwara H, Okamoto K, Otsuji E. Circulating long noncoding RNAs in plasma of patients with gastric cancer. Anticancer Res. 2013; 33:3185-93.

97. Zhou X, Yin C, Dang Y, Ye F, Zhang G. Identification of the long non-coding RNA H19 in plasma as a novel biomarker for diagnosis of gastric cancer. Sci Rep. 2015; 5:11516. https://doi.org/10.1038/srep11516.

98. Yang T, Zeng H, Chen W, Zheng R, Zhang Y, Li Z, Qi J, Wang M, Chen T, Lou J, Lu L, Zhou T, Dai S, et al. Helicobacter pylori infection, H19 and LINC00152 expression in serum and risk of gastric cancer in a Chinese population. Cancer Epidemiol. 2016; 44:147-53. https://doi. org/10.1016/j.canep.2016.08.015.

99. Li Q, Shao Y, Zhang X, Zheng T, Miao M, Qin L, Wang B, Ye G, Xiao B, Guo J. Plasma long noncoding RNA protected by exosomes as a potential stable biomarker for gastric cancer. Tumour Biol. 2015; 36:2007-12. https://doi. org/10.1007/s13277-014-2807-y.

100. Jin C, Shi W, Wang F, Shen X, Qi J, Cong H, Yuan J, Shi L, Zhu B, Luo X, Zhang Y, Ju S. Long non-coding RNA HULC as a novel serum biomarker for diagnosis and prognosis prediction of gastric cancer. Oncotarget. 2016; 7:51763-72. https://doi.org/10.18632/oncotarget.10107.

101. Dong L, Qi P, Xu MD, Ni SJ, Huang D, Xu QH, Weng WW, Tan C, Sheng WQ, Zhou XY, Du X. Circulating CUDR, LSINCT-5 and PTENP1 long noncoding RNAs in sera distinguish patients with gastric cancer from healthy controls. Int J Cancer. 2015; 137:1128-35. https://doi. org/10.1002/ijc.29484.

102. Liu Z, Shao Y, Tan L, Shi H, Chen S, Guo J. Clinical significance of the low expression of FER1L4 in gastric cancer patients. Tumour Biol. 2014; 35:9613-17. https:// doi.org/10.1007/s13277-014-2259-4.

103. Zeng X, Shi H, Wang J, Cui S, Tang H, Zhang X. Long noncoding RNA aberrant expression profiles after cytoreductive surgery and hyperthermic intraperitoneal 
chemotherapy of AGC ascertained by microarray analysis. Tumour Biol. 2015; 36:5021-29. https://doi.org/10.1007/ s13277-015-3153-4.

104. Chao Y, Hsieh JS, Yeh HT, Su YC, Wu CC, Chen JS, Tai CJ, Bai LY, Yeh KH, Su WC, Li CP. A multicenter phase II study of biweekly capecitabine in combination with oxaliplatin as first-line chemotherapy in patients with locally advanced or metastatic gastric cancer. Cancer Chemother Pharmacol. 2014; 73:799-806. https://doi.org/10.1007/s00280-0142407-y. 